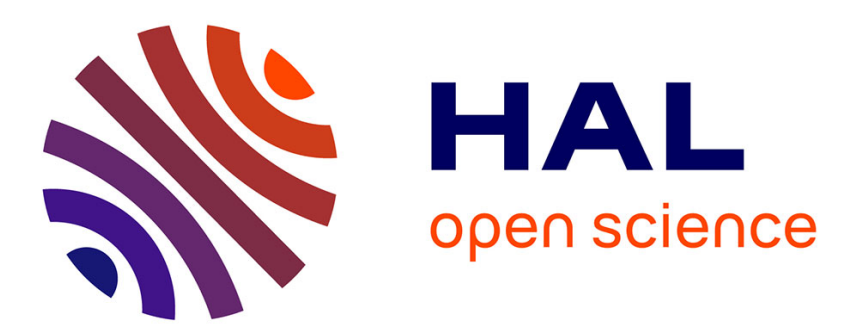

\title{
Interactions of organophosphorus pesticides with solute carrier (SLC) drug transporters
}

\author{
Lisa Chedik, Arnaud Bruyère, Olivier Fardel
}

\section{To cite this version:}

Lisa Chedik, Arnaud Bruyère, Olivier Fardel. Interactions of organophosphorus pesticides with solute carrier (SLC) drug transporters. Xenobiotica, 2019, 49 (3), pp.363-374. 10.1080/00498254.2018.1442030. hal-01863798

\section{HAL Id: hal-01863798}

\section{https://hal-univ-rennes1.archives-ouvertes.fr/hal-01863798}

Submitted on 9 Nov 2018

HAL is a multi-disciplinary open access archive for the deposit and dissemination of scientific research documents, whether they are published or not. The documents may come from teaching and research institutions in France or abroad, or from public or private research centers.
L'archive ouverte pluridisciplinaire HAL, est destinée au dépôt et à la diffusion de documents scientifiques de niveau recherche, publiés ou non, émanant des établissements d'enseignement et de recherche français ou étrangers, des laboratoires publics ou privés. 
Interactions of organophosphorus pesticides with solute carrier (SLC) drug transporters

Lisa CHEDIK ${ }^{\mathrm{a}}$, Arnaud BRUYERE ${ }^{\mathrm{a}}$ and Olivier FARDEL ${ }^{\mathrm{a}, \mathrm{b}, *}$

${ }^{a}$ Institut de Recherches en Santé, Environnement et Travail (IRSET), UMR INSERM U1085, Université de Rennes 1, 2 Avenue du Pr Léon Bernard, 35043 Rennes, France

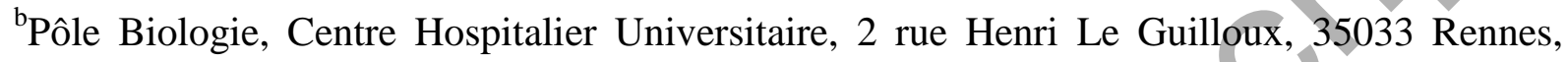
France

* Corresponding author.

Tel : 332232348 90. Fax : 332232347 94. E-mail: olivier.fardel@ univ-rennes1.fr 
Interactions of organophosphorus pesticides with solute carrier (SLC) drug transporters

\section{Summary}

1. Organophosphorus pesticides (OPs) are known to interact with human ATP-binding cassette drug efflux pumps. The present study was designed to determine whether they can also target activities of human solute carrier (SLC) drug transporters.

2. The interactions of thirteen OPs with SLC transporters involved in drug disposition, such as organic cation transporters (OCTs), multidrug and toxin extrusion proteins (MATEs), organic anion transporters (OATs) and organic anion transporting polypeptides (OATPs), were mainly investigated using transporter-overexpressing cell clones and fluorescent or radiolabeled reference substrates.

3. With a cut-off value of at least $50 \%$ modulation of transporter activity by $100 \mu \mathrm{M}$ OPs, OAT1 and MATE2-K were not impacted, whereas OATP1B1 and MATE1 were inhibited by two and three OPs, respectively. OAT3 activity was similarly blocked by three OPs, and was additionally stimulated by one OP. Five OPs cis-stimulated OATP2B1 activity. Both OCT1 and OCT2 were inhibited by the same eight OPs, including fenamiphos and phosmet, with $\mathrm{IC}_{50}$ values however in the $3-30 \mu \mathrm{M}$ range, likely not relevant to environmental exposure.

4. These data demonstrated that various OPs inhibit SLC drug transporter activities, especially those of OCT1 and OCT2, but only when used at high concentrations not expected to occur in environmentally-exposed humans.

Key-words: organophosphorus pesticide; drug transporter; solute carrier; dopamine; molecular descriptors. 


\section{Introduction}

Drug transporters are membrane proteins belonging to the ATP-binding cassette (ABC) or to the solute carrier (SLC) transporter families (Doring and Petzinger 2014). ABC transporters such as P-glycoprotein, encoded by the MDRI/ABCBI gene, multidrug resistance-associated proteins (MRPs/ABCCs) and breast cancer resistance protein (BCRP/ABCG2), are ATPases acting as unidirectional drug efflux pumps (Schinkel and Jonker 2003). SLC transporters mediate either facilitated diffusion or secondary active transport and may act as bidirectional transporters; in physiological situations, most of them are however implicated in drug uptake into cells (Colas et al., 2016). Both ABC and SLC transporters play a major role in pharmacokinetics (Giacomini et al., 2010). They are notably involved in the different steps of drug disposition, i.e., intestinal absorption, passage across blood-tissue barriers such as the blood-brain barrier, and hepatic and renal excretion (Shitara et al., 2006; Szakacs et al., 2008). Drug-mediated inhibition of their activity can consequently cause pharmacokinetics-based drug-drug interactions (Konig et al., 2013), which has led drug regulatory agencies to edict guidances for the study of putative interactions of new molecular entities with clinically-relevant drug transporters (Prueksaritanont et al., 2013). Blockage of drug transporters can additionally result in altered transport of endogenous substrates, which can cause drug toxicity (DeGorter et al., 2012).

In addition to drugs, various environmental chemicals have been shown to interact with drug transporters, i.e., they are substrates and/or modulators of $\mathrm{ABC}$ and/or SLC transporters (Fardel et al., 2012). This notably concerns chemical pesticides, to which humans are widely exposed and which are proposed to exert deleterious effects towards human health, including endocrine disruption, carcinogenicity and development of neurologic diseases (Maroni and Fait 1993; Mostafalou and Abdollahi 2017). Indeed, diverse structurally- and pharmacologically-unrelated pesticides interfere with P-glycoprotein activity (Bain and 
LeBlanc 1996), whereas various organochlorine insecticides and the pyrethroids allethrin and tetramethrin block activities of the SLC transporter organic cation transporter (OCT) 1 (SLC22A1) and of the ABC transporters MRP2 (ABCC2) and BCRP (Bucher et al., 2014; Chedik et al., 2017). Herbicides such as chloroacetanilide compounds have additionally been shown to interfere with various $\mathrm{ABC}$ transporters (Oosterhuis et al., 2008). It is also the case for organophosphorus pesticides (OPs), which chemically correspond to esters, amides, or thiol derivatives of phosphoric, phosphonic, phosphorothioic, or phosphonothioic acids, and constitute a major and widely-used class of insecticides or herbicides (Mostafalou and Abdollahi 2017). Indeed, some OPs are thought to be transported by human ABC pumps; diazinon is thus most likely a substrate for P-glycoprotein (Cavret et al., 2005; Lacher et al., 2015), whereas MRP1 may handle fenitrothion (Tribull et al., 2003). Moreover, chlorpyrifos may be transported by rabbit BCRP (Tribull et al., 2003), and methyl parathion has been suggested to be expelled by P-glycoprotein and MRP4/ABCC4 in Zebrafish liver cells (Nornberg et al., 2015). Various OPs have additionally been demonstrated to inhibit ABC transporter activities. For example, coumaphos, chlorthiophos, leptophos, fenamiphos, dicapthon, parathion, phosalone, methyl parathion, chlorpyrifos and methyl chlorpyrifos block P-glycoprotein (Bain and LeBlanc 1996; Bain et al., 1997; Pivcevic and Zaja 2006; Sreeramulu et al., 2007). By contrast, whether OPs may interact with SLC drug transporters remains unknown, but is probably important to determine owing to the relevance of SLC drug transporters in toxicokinetics and toxicity of environmental chemicals (Fardel et al., 2012) and to the wide exposure of humans to OPs, which may result in adverse health effects (Androutsopoulos et al., 2013; Munoz-Quezada et al., 2013). The present study was therefore designed to characterize the interactions of thirteen OPs with main SLC drug transporters, handling organic cations, like OCT1, OCT2/SLC22A2, multidrug and toxin extrusion protein (MATE) 1 (SLC47A1) and MATE2-K (SLC47A2), or organic anions, like organic anion 
transporter (OAT) 1 (SLC22A6), OAT3 (SLC22A8), organic anion transporting polypeptide (OATP) 1B1 (SLCO1B1) and OATP2B1 (SLCO2B1). Our data indicate that OPs differentially interact with SLC transporters. OCT1 and OCT2, mainly expressed at the basolateral pole of hepatocytes and proximal tubular cells, respectively (Jonker and Schinkel 2004), are the most impacted transporters. Indeed, 8/13 OPs inhibit the functional activity of these OCT transporters when, however, used at concentrations not relevant to environmental exposure and, without, at least for fenamiphos and phosmet, being substrates.

\section{Materials and Methods}

\section{Chemicals}

OPs, rhodamine 123, verapamil, probenecid, amitriptyline, fluorescein, 4',6'diamidino-2-phenylindole (DAPI), and tetra-ethylammonium bromide (TEA) were provided by Sigma-Aldrich (Saint-Quentin Fallavier, France). [1- $\left.{ }^{14} \mathrm{C}\right]-\mathrm{TEA}$ (sp. act. $3.5 \mathrm{mCi} / \mathrm{mmol}$ ), $\left[6,7-{ }^{3} \mathrm{H}(\mathrm{N})\right]$-estrone-3-sulfate $(\mathrm{E} 3 \mathrm{~S}) \quad(\mathrm{sp} . \quad$ act. $51.8 \mathrm{Ci} / \mathrm{mmol})$ and 3,4-[Ring-2,5,6- $\left.{ }^{3} \mathrm{H}\right]-$ dihydroxyphenylethylamine (dopamine) (sp. act. $46 \mathrm{Ci} / \mathrm{mmol}$ ) were purchased from PerkinElmer (Boston, MA, USA). Stocked solutions of chemicals were commonly prepared in dimethyl sulfoxide (DMSO); final concentrations of solvent in transport assay medium did not exceed $0.2 \%$ (vol/vol). The chemical structures of the thirteen OPs analyzed in the study are shown in Supplementary Fig. 1. Six of these OPs, i.e., dichlorvos, fenamiphos, metasystox, methamidophos, monocrotophos, and profenofos, were organophosphate pesticides, with a central phosphorus atom with double bonded oxygen $(\mathrm{P}=\mathrm{O})$. The remaining OPs $(\mathrm{n}=7)$, i.e., fenitrothion, malathion, methyl parathion, parathion, phosmet, propetamphos and temephos, were organothiophosphates compounds, with a central phosphorus atom with double bonded sulfur atom $(\mathrm{P}=\mathrm{S})$. These thion $\mathrm{OPs}$ have to be metabolized in oxon metabolites by cytochrome P-450 enzymes, for inhibiting acetylcholinesterase (Elersek and 
Filipic 2011). According to the PubChem database (U.S. National Library of Medicine, Bethesda, MA, USA), all OPs tested in the study were predicted to be water-soluble at 100 $\mu \mathrm{M}$, which was the OP concentration retained for initially screening their potential inhibitory effects towards SLC transporter activities.

\section{Cell culture}

Human HEK293 cells stably overexpressing OCT1 (HEK-OCT1 cells), OCT2 (HEKOCT2), MATE1 (HEK-MATE1 cells), MATE2-K (HEK-MATE2-K cells), OAT1 (HEKOAT1 cells), OAT3 (HEK-OAT3 cells), OATP1B1 (HEK-OATP1B1) or OATP2B1 (HEKOATP2B1 cells), as well as control HEK-MOCK cells were cultured in DMEM medium (Thermo Fisher Scientific, Villebon sur Yvette, France) containing 4.5 g/L D-glucose and supplemented with $10 \%$ (vol/vol) fetal calf serum, 1\% (vol/vol) MEM non-essential amino acids solution (Thermo Fisher Scientific), $1 \mu \mathrm{g} / \mathrm{mL}$ bovine insulin (Sigma-Aldrich), $20 \mathrm{UI} / \mathrm{mL}$ penicillin and $20 \mu \mathrm{g} / \mathrm{mL}$ streptomycin. Generation and characterization of these SLC transporter-overexpressing HEK293 cells have been previously described (Chedik et al., 2017; Jouan et al., 2014). For functional assays, cells were plated in 48-wells multiplates coated with poly-D-lysine to enhance cell adhesion, at a density of $4 \times 10^{4}$ cells/well, and were used when reaching confluency, i.e., typically after culturing them for 5 days after seeding.

Human hepatocytes were obtained from adult donors undergoing hepatic resection for tumors. The processing of biological samples was performed through the Centre de Ressources Biologiques (CRB) Santé of Rennes BB-0033-00056, conducted under French legal guidelines and fulfilled the requirements of the local institutional ethics committee. They were seeded at a density of $2 \times 10^{5}$ cells $/ \mathrm{cm}^{2}$ in Williams' E medium (Thermo Fisher Scientifics), supplemented with $10 \%$ (vol/vol) fetal calf serum, $5 \mu \mathrm{g} / \mathrm{mL}$ bovine insulin, 20 IU/mL penicillin, $20 \mu \mathrm{g} / \mathrm{mL}$ streptomycin, and $2 \mathrm{mM}$ glutamine. After $24 \mathrm{~h}$, this seeding 
medium was discarded, and primary hepatocytes were routinely cultured in the fetal calf serum-containing Williams' E medium defined above and supplemented with $5 \times 10^{-5} \mathrm{M}$ hydrocortisone hemisuccinate (SERB laboratoires, Paris, France) and 2\% (vol/vol) DMSO, as previously reported (Le Vee et al., 2015).

Human highly differentiated hepatoma HepaRG cells were routinely cultured in Williams' E medium supplemented with $10 \%$ (vol/vol) fetal calf serum, $20 \mathrm{IU} / \mathrm{mL}$ penicillin, $20 \mu \mathrm{g} / \mathrm{mL}$ streptomycin, $2 \mathrm{mM}$ glutamine, and $5 \times 10^{-5} \mathrm{M}$ hydrocortisone hemisuccinate; additional culture for two weeks in the same medium supplemented with $2 \%$ (vol/vol) DMSO was performed in order to get a full hepatocytic differentiation of the cells (Le Vee et al., 2013).

\section{Transporter assays}

Transporter assays were performed essentially as previously described (Chedik et al., 2017).

Briefly, for $c$ is-inhibition studies, cells were incubated for $5 \mathrm{~min}$ at $37^{\circ} \mathrm{C}$ in a transport assay buffer containing a radiolabeled or fluorescent substrate of the considered transporter, in the presence or absence of a reference inhibitor or OPs. The 5 min incubation time with substrates is commonly used for transport assays (Ahlin et al., 2008; Chedik et al., 2017); moreover, it has been previously shown to be comprised in the linear phase of substrate accumulation, at least for the OCT substrate rhodamine 123 and HEK-OCT cells (Jouan et al., 2014). The transport assay buffer was composed of $136 \mathrm{mM} \mathrm{NaCl}, 5.3 \mathrm{mM} \mathrm{KCl}, 1.1 \mathrm{mM}$ $\mathrm{KH}_{2} \mathrm{PO}_{4}, 0.8 \mathrm{mM} \mathrm{MgSO}$, $1.8 \mathrm{mM} \mathrm{CaCl} 2,10 \mathrm{mM}$ HEPES, $11 \mathrm{mM}$ D-glucose, adjusted to $\mathrm{pH}=7.4$ (excepted for organic cation/proton exchangers MATEs for which $\mathrm{pH}$ was set at 8.4). Nature and concentrations of substrates and inhibitors used for each investigated SLC transporter are indicated in Supplementary Table 1. Cells were next washed twice with ice- 
cold phosphate-buffered saline (PBS), and lysed in distilled water. For fluorescent substrates, their intracellular accumulations were determined by spectrofluorimetry using a SpectraMax Gemini SX spectrofluorometer (Molecular Devices, Sunnyvale, CA); excitation and emission wavelengths were 485 and $535 \mathrm{~nm}$, respectively, for rhodamine 123 and fluorescein, and 355 and $460 \mathrm{~nm}$, respectively, for DAPI. For radiolabeled substrates, their intracellular accumulations were measured using a Beckman LS65000 scintillation counter (Beckman Coulter, Villepinte, France). Data were finally normalized to total protein content, determined by the Bradford's method (Bradford 1976). They were routinely expressed as \% of transporter activity according to the following equation:

$$
\% \text { Transporter activity }=\frac{\left(\left[\text { Substrate }_{\text {organophosphorus pesticide }}\right]-\left[\text { Substrate }_{\text {ref inh }}\right]\right) \times 100}{\left(\left[\text { Substrate }_{\text {control }}\right]-\left[\text { Substrate }_{\text {ref inh }}\right]\right)}
$$

with $\left[\right.$ Substrate $\left.{ }_{\text {organophosphorus pesticide }}\right]=$ cellular concentration of reference substrate in the presence of a defined concentration of OP, [Substrate refinh $_{\text {] }}=$ cellular concentration of reference substrate in the presence of reference inhibitor and $\left[\right.$ Substrate $\left._{\text {control }}\right]=$ cellular concentration of reference substrate in control cells not exposed to OP or reference inhibitor.

Some data were also expressed as \% of SLC transporter activity inhibition or as \% of SLC transporter activity stimulation, according to the following equations:

$\%$ Transporter activity inhibition $=100 \%-\%$ Transporter activity (in the presence of OP)

$\%$ Transporter activity stimulation $=\%$ Transporter activity (in the presence of OP) $-100 \%$

with \% Transporter activity (in the presence of OP) determined according to the equation (A).

For dopamine accumulation assays, data were expressed as percentage of OCT1- or OCT2-mediated transport of $\left[{ }^{3} \mathrm{H}\right]$-dopamine in control OP-unexposed cells, determined by subtracting accumulation of $\left[{ }^{3} \mathrm{H}\right]$-dopamine in HEK-MOCK cells from that in HEK-OCT1 or HEK-OCT2 cells in the absence of OPs, and arbitrarily set at $100 \%$. 
For OCT1- and OCT2-related trans-stimulation assays, HEK-OCT1 and HEK-OCT2 cells were initially loaded with $10 \mathrm{mM}$ unlabeled TEA or $100 \mu \mathrm{M}$ OPs for $60 \mathrm{~min}$ at $37^{\circ} \mathrm{C}$. After washing with ice-cold PBS, cells were re-incubated in the transport assay medium described above containing $29 \mu \mathrm{M}\left[{ }^{14} \mathrm{C}\right]$-TEA. After PBS washing, intracellular accumulation of $\left[{ }^{14} \mathrm{C}\right]$-TEA was monitored by scintillation counting as reported above. Data were expressed as percentage of $\left[{ }^{14} \mathrm{C}\right]$-TEA accumulation in control cells not loaded with unlabeled TEA or OPs, arbitrarily set at $100 \%$.

Determination of half maximal inhibitory concentrations $\left(I C_{50}\right)$

$\mathrm{IC}_{50}$ values of OPs towards transporter activities were determined using Prism 5.0 software (GraphPad Software, La Jolla, CA, USA) through nonlinear regression based on the following four-parameter logistic equation:

$$
\left.\mathrm{A}=\frac{100}{1+10((\mathrm{II}-\mathrm{Log}(\mathrm{C} 50) \times \mathrm{Hill} \text { slope })}\right)(\mathrm{D})
$$

where $\mathrm{A}$ is the percentage of transporter activity for a given concentration of OP determined as described in equation (A), $[\mathrm{I}]$ is the OP concentration in the medium, and Hill slope is a coefficient describing the steepness of the curve.

\section{Chemical combination assays}

The combined effects of the OPs fenamiphos and phosmet on OCT2 activity were evaluated by median drug effect analysis, as previously described (Chou 2010). Briefly, the inhibitory effects of combinations of fenamiphos and phosmet towards OCT2-mediated transport were studied as a fixed constant ratio (1:1), chosen according to the $\mathrm{IC}_{50}$ value of each chemical, using 2-fold serial dilutions with several concentration points below and above $\mathrm{IC}_{50}$ values of each OP used as a single chemical (Chou 2010). Data from combination and single chemical effects towards OCT2 activity were then processed using the CompuSyn 
software (ComboSyn, Inc., Paramus, NJ, USA), allowing thus to determine combination index $(\mathrm{CI})$ values. The $\mathrm{CI}$ is a numerical index that is calculated using the following equation (Zhao et al., 2004):

$$
\mathrm{CI}=\frac{\mathrm{C}_{\text {Fenamiphos/Mixture }}}{\mathrm{C}_{\text {Fenamiphos }}}+\frac{\mathrm{C}_{\text {Phosmet/Mixture }}}{\mathrm{C}_{\text {Phosmet }}}
$$

where $\mathrm{C}_{\text {Fenamiphos/Mixture }}$ and $\mathrm{C}_{\text {Phosmet/Mixture }}$ are the concentrations of fenamiphos and phosmet applied in combination to achieve $\mathrm{x} \%$ of OCT2 activity inhibition, whereas $\mathrm{C}_{\mathrm{Fenamiphos}}$ and $\mathrm{C}_{\text {Phosmet }}$ represent the concentrations of individual agents to accomplish the same efficacy. Combinations were considered as synergistic when $\mathrm{CI}<0.8$, additive when $0.8 \leq \mathrm{CI} \leq 1.2$ and antagonistic when $\mathrm{CI}>1.2$ (Bijnsdorp et al., 2011).

\section{OP accumulation assays}

HEK-MOCK, HEK-OCT1 and HEK-OCT2 cells were incubated with $100 \mu \mathrm{M}$ fenamiphos or $100 \mu \mathrm{M}$ phosmet, in the absence or presence of reference inhibitors $(100 \mu \mathrm{M}$ verapamil for OCT1 inhibition and $100 \mu \mathrm{M}$ amitriptyline for OCT2 inhibition), for $5 \mathrm{~min}$ at $37^{\circ} \mathrm{C}$, in the transport assay medium defined above. Cells were next washed twice in ice-cold PBS and lysed in distilled water. An acetonitrile-based extraction of cell lysates was further performed, following by OP quantification through liquid chromatography-tandem mass spectroscopy (LC-MS/MS), using an high-performance liquid chromatography Aria system (Agilent, Les Ulis, France), equipped with a Kromasyl ${ }^{\circledR} \mathrm{C} 18(4.6 \times 150 \mathrm{~mm})$ column (Interchim, Montluçon, France) and coupled to a tandem mass spectrometry TSQ Quantum Ultra (Thermo Fisher Scientific) fitted with an electrospray ionization source (ESI+). Monitored ion transitions were at $304.1>217.1 \mathrm{~m} / \mathrm{z}$ for fenamiphos and $318.0>160.0 \mathrm{~m} / \mathrm{z}$ for phosmet. Amounts of OPs were finally normalized to total protein cell content. 
Molecular descriptor generation for OPs was performed as previously described (Chedik et al., 2017). Briefly, OPs, initially expressed in SMILES format, were converted to 3D format using the Marvin View software (ChemAxon, Budapest, Hungary); conformers were generated at $\mathrm{pH}=7.0$, close to physiological $\mathrm{pH}$ values. Molecular descriptors were then generated using the Dragon ${ }^{\circledR} 7$ software (Talete, Milano, Italy), which provides 5270 molecular descriptors, divided on 30 blocks (See https://chm.kodesolutions.net/products_dragon_descriptors.php for a complete list of these descriptors).

\section{Statistical analysis}

Experimental data were routinely expressed as means \pm SEM. They were statistically analysed through ANOVA followed by a Dunnett's or a Bonferroni post-hoc test. Statistical analysis of molecular descriptors discriminating inhibitors from non-inhibitors of OCT1/OCT2 activities was performed using the non-parametric Mann-Whitney test. The criterion of significance was $\mathrm{p}<0.05$.

\section{Results}

Effects of OPs on organic anion transporter activities

The effects of $100 \mu \mathrm{M}$ OPs on uptakes of the OAT substrate fluorescein and of the OATP substrate $\left[{ }^{3} \mathrm{H}\right]-\mathrm{E} 3 \mathrm{~S}$ were studied in OAT1-, OAT3-, OATP1B1- and OATP2B1overexpressing HEK293 cells. As shown in Fig. 1, phosmet was the only OP which significantly impaired fluorescein uptake in HEK-OAT1 cells. It however reduced OAT1 activity by only $48.4 \%$, and thus failed to reach the threshold of $50 \%$ transporter activity reduction, commonly admitted for defining drug transporter inhibition (Ahlin et al., 2008; De Bruyn et al., 2013; Kido et al., 2011); this precludes to consider it as a relevant OAT1 
inhibitor (Table 1). With respect to OAT3-mediated uptake of fluorescein, it was significantly inhibited by fenamiphos, malathion and profenofos (Fig. 1), which blocked OAT3 activity by more than $50 \%$ and can therefore be considered as OAT3 inhibitors (Table 1). By contrast, metasystox and methyl parathion cis-stimulated fluorescein accumulation in HEK-OAT3 cells. With a cut-off of $50 \%$ increase for validating SLC transporter activity stimulation, only metasystox can however be considered as an OAT3 stimulator (Table 1).

Various OPs such as fenitrothion, methyl parathion, parathion, phosmet, profenofos and temephos significantly decreased $\left[{ }^{3} \mathrm{H}\right]-\mathrm{E} 3 \mathrm{~S}$ accumulation in HEK-OATP1B1 cells (Fig. 1). Only profenofos and temephos however inhibited OATP1B1 activity by more than $50 \%$ (Table 1). For OATP2B1-mediated transport of $\left[{ }^{3} \mathrm{H}\right]-\mathrm{E} 3 \mathrm{~S}$, several OPs, such as fenamiphos, malathion, parathion, phosmet and profenofos, significantly cis-stimulated it by more than $50 \%$ (Fig. 2), indicating that these pesticides can be considered as OATP2B1 stimulators (Table 1). None of OPs significantly decreased $\left[{ }^{3} \mathrm{H}\right]-\mathrm{E} 3 \mathrm{~S}$ uptake in HEK-OATP2B1 cells (Fig. 1).

\section{Effects of OPs on organic cation transporter activities}

The effects of $100 \mu \mathrm{M}$ OPs on uptakes of the OCT1 substrate DAPI, the OCT2 substrate rhodamine 123 and the MATE substrate $\left[{ }^{14} \mathrm{C}\right]-$ TEA were studied in OCT1-, OCT2-, MATE1- and MATE2-K-overexpressing HEK293 cells.

Several OPs were found to markedly cis-inhibited DAPI uptake in HEK-OCT1 cells and rhodamine 123 uptake in HEK-OCT2 cells by more than 50\% (Fig. 2). Fenamiphos, fenitrothion, malathion, methyl parathion, parathion, phosmet, profenofos and propetamphos appeared thus as OCT1 and OCT2 inhibitors (Table 1). Temephos also significantly inhibited DAPI uptake in HEK-OCT1 cells, but only by $29.1 \%$ (Fig. 2), thus precluding to consider it as an OCT1 inhibitor (Table 1). The same conclusion can also be drawn for the slight, but 
significant, temephos-mediated inhibition of rhodamine 123 accumulation in HEK-OCT2 cells (Fig. 2). Similarly, metasystox only weakly inhibited OCT2 activity (Fig. 2).

With respect to MATE1-mediated transport of $\left[{ }^{14} \mathrm{C}\right]-\mathrm{TEA}$, it was significantly inhibited by various OPs, including fenamiphos, fenitrothion, malathion, methyl parathion, parathion, phosmet, profenofos and propetamphos (Fig. 2). However, according to the $50 \%$ inhibition cut-off, only fenamiphos, phosmet and propetamphos can be considered as MATE1 inhibitors (Table 1). None of OPs were found to inhibit uptake of $\left[{ }^{14} \mathrm{C}\right]-\mathrm{TEA}$ in HEKMATE2-K cells (Fig. 2).

Characterization of fenamiphos and phosmet interactions with OCT1 and OCT2.

Because OCT1 and OCT2 are the most highly impacted SLC transporters by OPs, i.e., 8/13 OPs were found to be OCT1 and OCT2 inhibitors (Table 1), we next focused on OPsOCT1 and OCT2 interactions. For this purpose, we retained fenamiphos and phosmet as prototypical OPs inhibiting OCT1 and OCT2.

As shown in Fig. 3A, fenamiphos and phosmet used at $100 \mu \mathrm{M}$ were found to inhibit uptake of the prototypical OCT1 substrate $\left[{ }^{14} \mathrm{C}\right]$-TEA in both primary human hepatocytes and hepatoma HepaRG cells, which constitutively express functional OCT1 (Jigorel et al., 2005; Le Vee et al., 2013); this suggests that these two OPs can efficiently block TEA transport in physiologically-expressing OCT1 cells such as hepatocytes. Fenamiphos and phosmet were next shown to inhibit uptake of the endogenous OCT1/OCT2 substrate $\left[{ }^{3} \mathrm{H}\right]$-dopamine in both HEK-OCT1 and HEK-OCT2 cells (Fig. 3B). Such effects, as well as fenamiphos- and phosmet-mediated inhibitions of DAPI and rhodamine 123 transport, were concentrationdependent, with $\mathrm{IC}_{50}$ values ranging, for fenamiphos, from $2.8 \mu \mathrm{M}$ (for inhibition of OCT2mediated transport of dopamine) to $27.5 \mu \mathrm{M}$ (for inhibition of OCT1-mediated transport of DAPI), and for phosmet, from $3.6 \mu \mathrm{M}$ (for inhibition of OCT2-mediated transport of $\left[{ }^{3} \mathrm{H}\right]-$ 
dopamine) to $10.4 \mu \mathrm{M}$ (for inhibition of OCT1-mediated transport of DAPI) (Fig. 4). Besides fenamiphos and phosmet, other OPs, including malathion, parathion, methyl parathion and fenitrothion, displayed $\mathrm{IC}_{50}$ values towards OCT1 or OCT2 activity in the 3-12 $\mu \mathrm{M}$ range (Supplementary Fig. 2).

Because humans are usually exposed to mixtures of pesticides (Hernandez et al., 2013), the putative combined effect of these chemicals towards transporters have likely to be considered. In this context, the exact nature of pesticide mixture effects, i.e., synergistic, additive or antagonistic, may be important to determine. To get initial information about this point, we characterized the effects of the combination fenamiphos/phosmet towards OCT2 activity through calculating CI using the CompuSyn software. As shown in Table 2, low concentrations of fenamiphos/phosmet (up to $8.40 \mu \mathrm{M}$ ) were found to exert synergistic inhibition towards OCT2-mediated transport $(\mathrm{CI}<0.8)$, whereas higher concentrations $(14.18$ $26.85 \mu \mathrm{M})$ were additive $(0.8 \leq \mathrm{CI} \leq 1.2)$. Only the very high mixture concentration of 70.22 $\mu \mathrm{M}$ exhibited antagonistic effect $(\mathrm{CI}>1.2)$ (Table 2$)$.

The putative transport of fenamiphos and phosmet by OCT1 and OCT2 was next investigated. For this, we first analyzed whether the two OPs may trans-stimulate $\left[{ }^{14} \mathrm{C}\right]-\mathrm{TEA}$ uptake in HEK-OCT1 and HEK-OCT2 cells, which may constitute an argument in favor of their transport by OCT1 and/or OCT2 (Grundemann et al., 2003; Zhang et al., 1999). Preloading with fenamiphos and phosmet however did not result in trans-stimulation of $\left[{ }^{14} \mathrm{C}\right]-$ TEA uptake in both HEK-OCT1 and HEK-OCT2 cells (Fig 5A). By contrast, pre-loading with unlabeled TEA trans-stimulated $\left[{ }^{14} \mathrm{C}\right]$-TEA uptake (Fig. 5A), as expected for this OCT1/2 reference substrate (Zhang et al., 1999). Accumulation of fenamiphos and phosmet was next measured in HEK-MOCK, HEK-OCT1 and HEK-OCT2 cells using LC-MS/MS (Fig. 5B). HEK-MOCK, HEK-OCT1 and HEK-OCT2 cells exhibited similar cellular uptake of the two OPs (Fig.5B), whereas, by contrast, HEK-OCT1 and HEK-OCT2 cells displayed 
much higher accumulations of the reference substrates DAPI and rhodamine 123, respectively, than HEK-MOCK cells (Supplementary Fig. 3). Moreover, the reference OCT1 inhibitor verapamil as well as the reference OCT2 inhibitor amitriptyline failed to impair accumulation of fenamiphos and phosmet in HEK-OCT1 and HEK-OCT2 cells, respectively (Fig. 5B). By contrast, verapamil inhibited DAPI accumulation in HEK-OCT1 cells and amitriptyline blocked that of rhodamine 123 in HEK-OCT2 cells (Supplementary Fig. 3).

\section{Determination of molecular descriptors associated with OCT1 and OCT2 inhibition by OPs.}

In order to identify the specific physico-chemical properties associated to OCT1 and OCT2 inhibition by 8/13 OPs, molecular descriptors, including 0D-constitutional, 1Dstructural, 2D-topological and 3D-geometrical descriptors, were determined using Dragon® 7 software. Putative associations with OCT1/OCT2 activity inhibition were next analyzed using the nonparametric Mann-Whitney test. As shown in Supplementary Table 2, OCT1/OCT2 inhibition by OPs was significantly associated with 234 molecular descriptors, representing $4.4 \%$ of the total number of descriptors. The values for the five most discriminating factors, i.e., those exhibiting the highest significance levels $(\mathrm{p}<0.002)$, are shown in Supplementary Fig. 4. The complete list of discriminating molecular factors, belonging to various block of descriptors, is provided in Supplementary Table 3. None of constitutional indices, that represent descriptors, like molecular weight/MW or van der Waals volume/Sv, commonly considered with respect to transporter inhibition (Ahlin et al., 2008; Kido et al., 2011), was found to discriminate OCT1/OCT2 inhibitors and non-inhibitors among OPs. In the same way, the numbers of hydrogen bond donors (nHDon) and acceptors (nHAcc), as well as lipophilicity-related descriptors (MLOGP and total polar surface area/TPSA) did not segregate inhibitors and non-inhibitors OPs (data not shown). 


\section{Discussion}

The present study demonstrated that various OPs can directly modulate activities of SLC drug transporters, thus indicating that these synthetic chemicals can interact with this family of drug transporters, like other pesticides, such as organochlorine and pyrethroid pesticides (Bucher et al., 2014; Chedik et al., 2017). SLC drug transporters can therefore be included in the growing list of off-targets of OPs, primarily designed as acetylcholinesterase inhibitors (Natoff 1971), but known to interfere with various molecular and biochemical processes (Elersek and Filipic 2011), notably related to endocrine receptors (Tamura et al., 2003) or to enzymes, including carboxylases, lipases and drug metabolizing enzymes like cytochromes P-450 (Hodgson and Rose 2006).

Any general and non-specific effects of OPs towards membrane SLC transporter activities can be discarded, because interactions of OPs with SLC transporters greatly vary according to the nature of transporters and OPs, as summarized in Table 1. Thus, OAT1 and MATE2-K were not impacted by any OP, whereas OATP1B1 and MATE1 were cis-inhibited by two and three OPs, respectively. OAT3 activity was similarly blocked by three OPs, and was additionally stimulated by one OP, i.e., metasystox. Five OPs cis-stimulated OATP2B1 activity, knowing that the molecular basis of SLC transporter cis-stimulation, as well as the putative relevance in terms of pharmacokinetics, remain yet poorly characterized. Both OCT1 and OCT2 were the most impacted transporters, i.e., their activity was inhibited by the same eight OPs. In addition, when considering OPs, some of them, like dichlorvos, methamidophos and monocrotophos, failed to inhibit activity of any transporter, whereas others impacted one (metasystox and temephos), two (fenitrothion and methyl parathion), three (propetamphos and parathion), four (malathion and phosmet) or five transporters (fenamiphos, profenofos) (Table 1). Importantly a same OP, like for example phosmet or profenofos, can cis-stimulate one SLC transporter, i.e., OATP2B1, and can concomitantly cis-inhibit others, such as OCT1 and 
OCT2. Taken together, these data illustrate the fact that structural requirements for interacting with SLC transporters are likely transporter-specific and are rather stringent, thus explicating why various OPs can differentially affect a same transporter. OCT1 and OCT2 were nevertheless cis-inhibited by the same OPs, thus highlighting that these two related transporters exhibiting marked similarities for both substrates and inhibitors, as previously underlined (Jonker and Schinkel 2004).

The structural requirements for both OCT1 and OCT2 inhibition by OPs have been investigated in a more detailed manner. They include various molecular descriptors, which belong to different blocks, thus highlighting their diversity. It is however noteworthy that the exact signification and/or practical relevance of most of these descriptors may be rather complex to apprehend. More intuitive descriptors, notably those linked to lipophilicity $(\log P)$, polar surface area or number of hydrogen bond donors or acceptors, failed to discriminate OPs inhibitors from non-inhibitors for OCT1/OCT2 activity. By contrast, some of these basic molecular descriptors have been demonstrated to be associated with OCT1 or OCT2 inhibition in previous studies (Ahlin et al., 2008; Kido et al., 2011). Such studies are however based on the analysis of much larger sets of chemicals ( $\mathrm{n}=191$ (Ahlin et al., 2008) or $\mathrm{n}=910$ (Kido et al., 2011)), than that of OPs $(\mathrm{n}=13)$ used in the present study. Moreover, they include compounds belonging to various and diverse structurally-unrelated chemical classes, whereas our study was restricted to one structural chemical family, i.e., that of OPs. Such differences in the number, the nature and the perimeter of analyzed chemicals may contribute to the discrepancies observed in terms of relevant discriminating molecular factors for OCT1/OCT2 inhibition.

OPs are suspected to exert various adverse effects towards human health (Koureas et al., 2012). Besides severe parasympathetic system dysfunction and mortality due to marked inhibition of acetylcholinesterase enzyme activity observed in acute OP poisoning 
(Chowdhary et al., 2014; Vale 2015), chronic exposure to OPs, which may occur in an occupational, domestic or environmental context, is thought to cause or promote cancers (Alavanja et al., 2004; Guyton et al., 2015), immunotoxicity (Li et al., 2002), endocrine disruption (Kang et al., 2004), alterations of child development (Gonzalez-Alzaga et al., 2015) and neurologic, cognitive and psychiatric disorders (Fiedler et al., 1997; Stephens et al., 1995). The possible contribution of SLC transporter activity alteration by OPs to these toxic effects is currently unknown. An implication of OPs-mediated changes in transport of endogenous substrates for the SLC transporters targeted by OPs may however be considered. The fact that both fenamiphos and phosmet markedly inhibited OCT1- and OCT2-mediated transport of dopamine in a concentration-dependent manner may be consistent with this hypothesis, knowing that alteration of dopaminergic ways plays a crucial role in Parkinson's disease, for which OP exposure is a well-established risk factor (Paul et al., 2016). A potential link between this neurodegenerative disorder, OPs and the $\mathrm{ABC}$ transporter P-glycoprotein, has moreover been recently suggested (Narayan et al., 2015), thus supporting the assertion that the interplay drug transporters-pesticides may contribute to pesticide toxicity. Besides dopamine transport, that of the endocrine compound E3S, which is either inhibited or stimulated by OPs, may deserve special attention, notably in relation with putative hormonal effects caused by OPs.

It should however be kept in mind that a critical point to consider is the in vivo relevance of the SLC transporter activity modulations by OPs established in in vitro assays. In this context, the in vitro $\mathrm{IC}_{50}$ values of various $\mathrm{OPs}$ such as fenamiphos, fenitrothion, malathion, methyl parathion, parathion and phosmet, required for inhibiting OCT1 and/or OCT2 activity, are in the $3-30 \mu \mathrm{M}$ range and are thus much higher than OP concentrations commonly measured in blood samples of humans environmentally exposed to pesticides, which are in the 1-200 pM range (Barr et al., 2002; Naksen et al., 2016; Whyatt et al., 2003). 
In this context, it is moreover noteworthy that plasma concentrations of unbound OPs, which have to be formally considered for OP effects, may be hypothesized to be even much weaker. By contrast, blood OP concentrations may reach 1-10 $\mu \mathrm{M}$ after acute poisoning (Salm et al., 2009). According to the US Food and Drug Administration criteria for evaluating the clinical relevance of in vitro transporter inhibition by chemicals (Giacomini et al., 2010), an in vivo transporter inhibition has to be considered when the ratio $[\mathrm{I}] / \mathrm{IC}_{50}>0.1$ (with $\mathrm{IC}_{50}$ as the xenobiotic concentration inhibiting in vitro $50 \%$ of the activity of the considered transporter and $[\mathrm{I}]$ as the $\mathrm{C}_{\max }$ maximal plasma concentration of the xenobiotic). When applying this regulatory criteria to OPs-mediated inhibition of OCT1/OCT2 activities, clinical inhibition of OCT1 and OCT2 by OPs may occur after acute poisoning ([I]/ $/ \mathrm{IC}_{50}$ around $\left.0.3-3\right)$, but not in response to environmental exposure $\left([\mathrm{I}] / \mathrm{IC}_{50}<0.0001\right)$. In vivo relevance of SLC transporter inhibition, especially those of OCT1 and OCT2, after environmental exposure to OPs can therefore probably be excluded. It should however be kept in mind that humans are generally exposed to mixtures of pesticides and other environmental chemicals, which may also interact with drug transporters (Bucher et al., 2014; Chedik et al., 2017; Nicklisch et al., 2016). Plasma levels of a single OP associated with those of other OPs, pesticides of pollutants, may therefore be sufficient to contribute to synergic or additive inhibitory effects towards drug transporters, as already described for pesticide combinations (Pivcevic and Zaja 2006). The fact that the combination of low concentrations of fenamiphos and phosmet exerts synergistic inhibition towards OCT2 activity fully supports this hypothesis.

ABC drug transporters have been shown to handle some OPs (Lacher et al., 2015; Tribull et al., 2003), and by this way, may be implicated in their pharmacokinetics. With respect to SLC drug transporters, OPs such as fenamiphos and phosmet failed to transstimulate OCT1 and OCT2 activity. In addition, intracellular accumulations of these two OPs in HEK-MOCK, HEK-OCT1 and HEK-OCT2 cells were similar and not impaired by 
reference OCT1 and OCT2 inhibitors. Taken together, these data suggest that fenamiphos and phosmet are not transported by OCT1 or OCT2. OPs may consequently modulate SLC transporter activities, without being transported, as already suggested for pyrethroids (Chedik et al., 2017). A major contribution of SLC drug transporters to OP biokinetics is therefore unlikely. The fact that metabolites of OPs, including oxon derivatives for organothiophosphates, may be substrates for SLC transporters may however challenge this assertion.

In summary, OPs were found to modulate activity of various SLC drug transporters. In particular, fenamiphos and phosmet inhibited activities of OCT1 and OCT2, without nevertheless being handled by these transporters. Such interactions with SLC transporters however occurred for OP concentrations much higher than those commonly expected in response to environmental exposure, making unlikely any relevant contribution of SLC transporter modulation to OP toxicity in environmentally-exposed humans.

\section{Acknowledgements}

We thank Dr D. Mias-Lucquin for his kind help for statistical analysis of molecular descriptor data and Dr Y. Parmentier and Dr C. Denizot for helpful support with HEK293 cell clones overexpressing transporters. The authors also acknowledge the Centre de Ressources Biologiques (CRB) Santé of Rennes BB-0033-00056 for managing hepatocyte supply and Technologie Servier (Orléans, France) for the gift of the LC-MS/MS system. 


\section{References}

Ahlin G, Karlsson J, Pedersen JM, Gustavsson L, Larsson R, Matsson P, Norinder U, Bergstrom CA, Artursson P. (2008). Structural requirements for drug inhibition of the liver specific human organic cation transport protein 1. J Med Chem, 51, 5932-42.

Alavanja MC, Dosemeci M, Samanic C, Lubin J, Lynch CF, Knott C, Barker J, Hoppin JA, Sandler DP, Coble Jet al., . (2004). Pesticides and lung cancer risk in the agricultural health study cohort. Am J Epidemiol, 160, 876-85.

Androutsopoulos VP, Hernandez AF, Liesivuori J, Tsatsakis AM. (2013). A mechanistic overview of health associated effects of low levels of organochlorine and organophosphorous pesticides. Toxicology, 307, 89-94.

Bain LJ, LeBlanc GA. (1996). Interaction of structurally diverse pesticides with the human MDR1 gene product P-glycoprotein. Toxicol Appl Pharmacol, 141, 288-98.

Bain LJ, McLachlan JB, LeBlanc GA. (1997). Structure-activity relationships for xenobiotic transport substrates and inhibitory ligands of P-glycoprotein. Environ Health Perspect, $105,812-8$.

Barr DB, Barr JR, Maggio VL, Whitehead RD, Jr., Sadowski MA, Whyatt RM, Needham LL. (2002). A multi-analyte method for the quantification of contemporary pesticides in human serum and plasma using high-resolution mass spectrometry. J Chromatogr B Analyt Technol Biomed Life Sci, 778, 99-111.

Bijnsdorp IV, Giovannetti E, Peters GJ. (2011). Analysis of drug interactions. Methods Mol Biol, 731, 421-34.

Bradford MM. (1976). A rapid and sensitive method for the quantitation of microgram quantities of protein utilizing the principle of protein-dye binding. Anal Biochem, 72, 248-54. 
Bucher S, Le Vee M, Jouan E, Fardel O. (2014). Regulation of hepatic drug transporter activity and expression by organochlorine pesticides. J Biochem Mol Toxicol, 28, $119-28$.

Cavret S, Videmann B, Mazallon M, Lecoeur S. (2005). Diazinon cytotoxicity and transfer in Caco-2 cells: Effect of long-term exposure to the pesticide. Environ Toxicol Pharmacol, 20, 375-80.

Chedik L, Bruyere A, Le Vee M, Stieger B, Denizot C, Parmentier Y, Potin S, Fardel O. (2017). Inhibition of Human Drug Transporter Activities by the Pyrethroid Pesticides Allethrin and Tetramethrin. PLoS One, 12, e0169480.

Chou TC. (2010). Drug combination studies and their synergy quantification using the ChouTalalay method. Cancer Res, 70, 440-6.

Chowdhary S, Bhattacharyya R, Banerjee D. (2014). Acute organophosphorus poisoning. Clin Chim Acta, 431, 66-76.

Colas C, Ung PM, Schlessinger A. (2016). SLC Transporters: Structure, Function, and Drug Discovery. Medchemcomm, 7, 1069-81.

De Bruyn T, van Westen GJ, Ijzerman AP, Stieger B, de Witte P, Augustijns PF, Annaert PP. (2013). Structure-based identification of OATP1B1/3 inhibitors. Mol Pharmacol, 83, 1257-67.

DeGorter MK, Xia CQ, Yang JJ, Kim RB. (2012). Drug transporters in drug efficacy and toxicity. Annu Rev Pharmacol Toxicol, 52, 249-73.

Doring B, Petzinger E. (2014). Phase 0 and phase III transport in various organs: combined concept of phases in xenobiotic transport and metabolism. Drug Metab Rev, 46, 26182.

Elersek T, Filipic O. (2011). Organophosphorous Pesticides - Mechanisms of Their Toxicity, Pesticides - The Impacts of Pesticides Exposure, Prof. Margarita Stoytcheva (Ed.), 
InTech,

DOI:

$10.5772 / 14020$.

Available

from:

https://www.intechopen.com/books/pesticides-the-impacts-of-pesticides-

exposure/organophosphorous-pesticides-mechanisms-of-their-toxicity.

Fardel O, Kolasa E, Le Vee M. (2012). Environmental chemicals as substrates, inhibitors or inducers of drug transporters: implication for toxicokinetics, toxicity and pharmacokinetics. Expert Opin Drug Metab Toxicol, 8, 29-46.

Fiedler N, Kipen H, Kelly-McNeil K, Fenske R. (1997). Long-term use of organophosphates and neuropsychological performance. Am J Ind Med, 32, 487-96.

Giacomini KM, Huang SM, Tweedie DJ, Benet LZ, Brouwer KL, Chu X, Dahlin A, Evers R, Fischer V, Hillgren KMet al., . (2010). Membrane transporters in drug development. Nat Rev Drug Discov, 9, 215-36.

Gonzalez-Alzaga B, Hernandez AF, Rodriguez-Barranco M, Gomez I, Aguilar-Garduno C, Lopez-Flores I, Parron T, Lacasana M. (2015). Pre- and postnatal exposures to pesticides and neurodevelopmental effects in children living in agricultural communities from South-Eastern Spain. Environ Int, 85, 229-37.

Grundemann D, Hahne C, Berkels R, Schomig E. (2003). Agmatine is efficiently transported by non-neuronal monoamine transporters extraneuronal monoamine transporter (EMT) and organic cation transporter 2 (OCT2). J Pharmacol Exp Ther, 304, 810-7.

Guyton KZ, Loomis D, Grosse Y, El Ghissassi F, Benbrahim-Tallaa L, Guha N, Scoccianti C, Mattock H, Straif K. (2015). Carcinogenicity of tetrachlorvinphos, parathion, malathion, diazinon, and glyphosate. Lancet Oncol, 16, 490-1.

Hernandez AF, Parron T, Tsatsakis AM, Requena M, Alarcon R, Lopez-Guarnido O. (2013). Toxic effects of pesticide mixtures at a molecular level: their relevance to human health. Toxicology, 307, 136-45. 
Hodgson E, Rose RL. (2006). Organophosphorus chemicals: potent inhibitors of the human metabolism of steroid hormones and xenobiotics. Drug Metab Rev, 38, 149-62.

Jigorel E, Le Vee M, Boursier-Neyret C, Bertrand M, Fardel O. (2005). Functional expression of sinusoidal drug transporters in primary human and rat hepatocytes. Drug Metab Dispos, 33, 1418-22.

Jonker JW, Schinkel AH. (2004). Pharmacological and physiological functions of the polyspecific organic cation transporters: OCT1, 2, and 3 (SLC22A1-3). J Pharmacol Exp Ther, 308, 2-9.

Jouan E, Le Vee M, Denizot C, Da Violante G, Fardel O. (2014). The mitochondrial fluorescent dye rhodamine 123 is a high-affinity substrate for organic cation transporters (OCTs) 1 and 2. Fundam Clin Pharmacol, 28, 65-77.

Kang HG, Jeong SH, Cho JH, Kim DG, Park JM, Cho MH. (2004). Chlropyrifos-methyl shows anti-androgenic activity without estrogenic activity in rats. Toxicology, 199, 219-30.

Kido Y, Matsson P, Giacomini KM. (2011). Profiling of a prescription drug library for potential renal drug-drug interactions mediated by the organic cation transporter 2. $\mathrm{J}$ Med Chem, 54, 4548-58.

Konig J, Muller F, Fromm MF. (2013). Transporters and drug-drug interactions: important determinants of drug disposition and effects. Pharmacol Rev, 65, 944-66.

Koureas M, Tsakalof A, Tsatsakis A, Hadjichristodoulou C. (2012). Systematic review of biomonitoring studies to determine the association between exposure to organophosphorus and pyrethroid insecticides and human health outcomes. Toxicol Lett, 210, 155-68.

Lacher SE, Skagen K, Veit J, Dalton R, Woodahl EL. (2015). P-Glycoprotein Transport of Neurotoxic Pesticides. J Pharmacol Exp Ther, 355, 99-107. 
Le Vee M, Jouan E, Noel G, Stieger B, Fardel O. (2015). Polarized location of SLC and ABC drug transporters in monolayer-cultured human hepatocytes. Toxicol In Vitro, 29, 93846.

Le Vee M, Noel G, Jouan E, Stieger B, Fardel O. (2013). Polarized expression of drug transporters in differentiated human hepatoma HepaRG cells. Toxicol In Vitro, 27, 1979-86.

Li Q, Nagahara N, Takahashi H, Takeda K, Okumura K, Minami M. (2002). Organophosphorus pesticides markedly inhibit the activities of natural killer, cytotoxic $\mathrm{T}$ lymphocyte and lymphokine-activated killer: a proposed inhibiting mechanism via granzyme inhibition. Toxicology, 172, 181-90.

Maroni M, Fait A. (1993). Health effects in man from long-term exposure to pesticides. A review of the 1975-1991 literature. Toxicology, 78, 1-180.

Mostafalou S, Abdollahi M. (2017). Pesticides: an update of human exposure and toxicity. Arch Toxicol, 91, 549-99.

Munoz-Quezada MT, Lucero BA, Barr DB, Steenland K, Levy K, Ryan PB, Iglesias V, Alvarado S, Concha C, Rojas Eet al., . (2013). Neurodevelopmental effects in children associated with exposure to organophosphate pesticides: a systematic review. Neurotoxicology, 39, 158-68.

Naksen W, Prapamontol T, Mangklabruks A, Chantara S, Thavornyutikarn P, Robson MG, Ryan PB, Barr DB, Panuwet P. (2016). A single method for detecting 11 organophosphate pesticides in human plasma and breastmilk using GC-FPD. J Chromatogr B Analyt Technol Biomed Life Sci, 1025, 92-104.

Narayan S, Sinsheimer JS, Paul KC, Liew Z, Cockburn M, Bronstein JM, Ritz B. (2015). Genetic variability in ABCB1, occupational pesticide exposure, and Parkinson's disease. Environ Res, 143, 98-106. 
Natoff IL. (1971). Organophosphorus pesticides: pharmacology. Prog Med Chem, 8, 1-37.

Nicklisch SC, Rees SD, McGrath AP, Gokirmak T, Bonito LT, Vermeer LM, Cregger C, Loewen G, Sandin S, Chang Get al., . (2016). Global marine pollutants inhibit Pglycoprotein: Environmental levels, inhibitory effects, and cocrystal structure. Sci Adv, 2, e1600001.

Nornberg BF, Batista CR, Almeida DV, Trindade GS, Marins LF. (2015). ABCB1 and ABCC4 efflux transporters are involved in methyl parathion detoxification in ZFL cells. Toxicol In Vitro, 29, 204-10.

Oosterhuis B, Vukman K, Vagi E, Glavinas H, Jablonkai I, Krajcsi P. (2008). Specific interactions of chloroacetanilide herbicides with human $\mathrm{ABC}$ transporter proteins. Toxicology, 248, 45-51.

Paul KC, Sinsheimer JS, Rhodes SL, Cockburn M, Bronstein J, Ritz B. (2016). Organophosphate Pesticide Exposures, Nitric Oxide Synthase Gene Variants, and Gene-Pesticide Interactions in a Case-Control Study of Parkinson's Disease, California (USA). Environ Health Perspect, 124, 570-7.

Pivcevic B, Zaja R. (2006). Pesticides and their binary combinations as P-glycoprotein inhibitors in NIH 3T3/MDR1 cells. Environ Toxicol Pharmacol, 22, 268-76.

Prueksaritanont T, Chu X, Gibson C, Cui D, Yee KL, Ballard J, Cabalu T, Hochman J. (2013). Drug-drug interaction studies: regulatory guidance and an industry perspective. AAPS J, 15, 629-45.

Salm P, Taylor PJ, Roberts D, de Silva J. (2009). Liquid chromatography-tandem mass spectrometry method for the simultaneous quantitative determination of the organophosphorus pesticides dimethoate, fenthion, diazinon and chlorpyrifos in human blood. J Chromatogr B Analyt Technol Biomed Life Sci, 877, 568-74. 
Schinkel AH, Jonker JW. (2003). Mammalian drug efflux transporters of the ATP binding cassette (ABC) family: an overview. Adv Drug Deliv Rev, 55, 3-29.

Shitara Y, Horie T, Sugiyama Y. (2006). Transporters as a determinant of drug clearance and tissue distribution. Eur J Pharm Sci, 27, 425-46.

Sreeramulu K, Liu R, Sharom FJ. (2007). Interaction of insecticides with mammalian Pglycoprotein and their effect on its transport function. Biochim Biophys Acta, 1768, $1750-7$.

Stephens R, Spurgeon A, Calvert IA, Beach J, Levy LS, Berry H, Harrington JM. (1995). Neuropsychological effects of long-term exposure to organophosphates in sheep dip. Lancet, 345, 1135-9.

Szakacs G, Varadi A, Ozvegy-Laczka C, Sarkadi B. (2008). The role of ABC transporters in drug absorption, distribution, metabolism, excretion and toxicity (ADME-Tox). Drug Discov Today, 13, 379-93.

Tamura H, Yoshikawa H, Gaido KW, Ross SM, DeLisle RK, Welsh WJ, Richard AM. (2003). Interaction of organophosphate pesticides and related compounds with the androgen receptor. Environ Health Perspect, 111, 545-52.

Tribull TE, Bruner RH, Bain LJ. (2003). The multidrug resistance-associated protein 1 transports methoxychlor and protects the seminiferous epithelium from injury. Toxicol Lett, $142,61-70$.

Vale A. (2015). Organophosphorus insecticide poisoning. BMJ Clin Evid, 2015.

Whyatt RM, Barr DB, Camann DE, Kinney PL, Barr JR, Andrews HF, Hoepner LA, Garfinkel R, Hazi Y, Reyes Aet al., . (2003). Contemporary-use pesticides in personal air samples during pregnancy and blood samples at delivery among urban minority mothers and newborns. Environ Health Perspect, 111, 749-56. 
Zhang L, Gorset W, Dresser MJ, Giacomini KM. (1999). The interaction of ntetraalkylammonium compounds with a human organic cation transporter, hOCT1. J Pharmacol Exp Ther, 288, 1192-8.

Zhao L, Wientjes MG, Au JL. (2004). Evaluation of combination chemotherapy: integration of nonlinear regression, curve shift, isobologram, and combination index analyses. Clin Cancer Res, 10, 7994-8004.

\section{Legends to figures}

Fig. 1. Effects of OPs on OAT/OATP activities. Activities of OAT1, OAT3, OATP1B1 and OATP2B1 were determined in OAT- and OATP-transfected HEK293 cells, using fluorescein (OATs) and $\left[{ }^{3} \mathrm{H}\right]-\mathrm{E} 3 \mathrm{~S}$ (OATPs) as reference substrates, in the absence or presence of the reference OAT/OATP inhibitor probenecid or of various OPs (each used at $100 \mu \mathrm{M}$ ), as described in Materials and Methods. Data are expressed as percentages of activities found in untreated control cells, arbitrarily set at $100 \%$ and indicated by dotted lines on graphs; they are the means \pm SEM of three independent assays, each being performed in triplicate. *, $\mathrm{p}<0.05$ when compared to untreated control cells.

Fig. 2. Effects of OPs on OCT/MATE activities. Activities of OCT1, OCT2, MATE1 and MATE2-K were determined in OCT- and MATE-transfected HEK293 cells, using DAPI (OCT1), rhodamine 123 (OCT2) and $\left[{ }^{14} \mathrm{C}\right]$-TEA (MATEs), as reference substrates, in the absence or presence of the reference inhibitors verapamil (OCT1 and MATEs) or amitriptyline (OCT2) or of various OPs (each used at $100 \mu \mathrm{M}$ ), as described in Materials and Methods. Data are expressed as percentages of activities found in untreated control cells, arbitrarily set at $100 \%$ and indicated by dotted lines on graphs; they are the means \pm SEM of 
three independent assays, each being performed in triplicate. ${ }^{*}, \mathrm{p}<0.05$ when compared to untreated control cells.

Fig. 3. Effects of fenamiphos and phosmet on accumulation of (A) $\left[{ }^{14} \mathrm{C}\right]-\mathrm{TEA}$ in primary human hepatocytes and HepaRG cells and (B) $\left[{ }^{3} \mathrm{H}\right]$-dopamine in HEK-OCT1 and HEKOCT2 cells. (A) Primary human hepatocytes and human HepaRG cells were incubated with $29 \mu \mathrm{M}\left[{ }^{14} \mathrm{C}\right]-\mathrm{TEA}$ in the absence (control) or presence of $100 \mu \mathrm{M}$ verapamil (used as a reference OCT1 inhibitor), $100 \mu \mathrm{M}$ fenamiphos or $100 \mu \mathrm{M}$ phosmet for $5 \mathrm{~min}$ at $37^{\circ} \mathrm{C}$. (B) HEK-OCT1, HEK-OCT2 and HEK-MOCK cells were incubated with $11 \mathrm{nM} 3,4$-[Ring-2,5,6${ }^{3} \mathrm{H}$ ]-dopamine in the absence (control) or presence of $100 \mu \mathrm{M}$ verapamil (used as a reference OCT1 and OCT2 inhibitor), $100 \mu \mathrm{M}$ fenamiphos or $100 \mu \mathrm{M}$ phosmet. (A, B) Intracellular accumulations of $\left[{ }^{14} \mathrm{C}\right]$-TEA and $\left[{ }^{3} \mathrm{H}\right]$-dopamine were then determined by scintillation counting and normalized to protein content. Data are expressed as percentages of $(\mathrm{A})\left[{ }^{14} \mathrm{C}\right]-$ TEA accumulation in control cells, arbitrarily set at $100 \%$ and indicated by dotted lines on graphs, or (B) OCT1- or OCT2-mediated transport of $\left[{ }^{3} \mathrm{H}\right]$-dopamine in control cells, determined by subtracting accumulation of $\left[{ }^{3} \mathrm{H}\right]$-dopamine in HEK-MOCK cells from that in HEK-OCT1 or HEK-OCT2 cells, in the absence of verapamil or OP, arbitrarily set at $100 \%$ and indicated by dotted lines on graphs. They are the means \pm SEM of three independent assays, each being performed in triplicate. ${ }^{*}, \mathrm{p}<0.05$ when compared to untreated control cells.

Fig. 4. Concentration-dependent effects of fenamiphos and phosmet towards OCT1 and OCT2 activities. OCT1 and OCT2 activities were determined using $\left[{ }^{3} \mathrm{H}\right]$-dopamine (OCT1 and OCT2), DAPI (OCT1) or rhodamine 123 (OCT2) as substrates, in the absence or presence of various concentrations of fenamiphos or phosmet (from 0.1 to $300 \mu \mathrm{M}$ ), as 
described in Materials and Methods. Data are expressed as percentages of transporter activities found in control untreated cells, arbitrarily set at $100 \%$; they are the means \pm SEM of three independent assays, each being performed in triplicate. $\mathrm{IC}_{50}$ values are indicated at the top of graphs.

\section{Fig. 5. Absence of handling of fenamiphos and phosmet by OCT1 and OCT2.}

(A) Lack of trans-stimulating effect of fenamiphos and phosmet towards OCT1- and OCT2mediated TEA uptake. HEK-OCT1 and HEK-OCT2 cells were first incubated for 60 min at $37^{\circ} \mathrm{c}$ in the absence (control) or presence of $10 \mathrm{mM}$ unlabeled TEA, $100 \mu \mathrm{M}$ fenamiphos or $100 \mu \mathrm{M}$ phosmet. After washing, cells were re-incubated with $29 \mu \mathrm{M}\left[{ }^{14} \mathrm{C}\right]-\mathrm{TEA}$ for 5 min at $37^{\circ} \mathrm{C}$. Intracellular accumulation of $\left[{ }^{14} \mathrm{C}\right]-\mathrm{TEA}$ was then determined by scintillation counting. Data are expressed as percentages of $\left[{ }^{14} \mathrm{C}\right]$-TEA accumulation in control cells, arbitrarily set at $100 \%$ and indicated by dotted lines on graphs; they are the means \pm SEM of three independent experiments. $*, \mathrm{p}<0.05$ when compared to control cells. (B) Accumulation of fenamiphos and phosmet in HEK-OCT1, HEK-OCT2 and HEK-MOCK cells. Cells were incubated with $100 \mu \mathrm{M}$ fenamiphos or $100 \mu \mathrm{M}$ phosmet, in the absence or presence of reference inhibitors $(100 \mu \mathrm{M}$ verapamil for OCT1 inhibition and $100 \mu \mathrm{M}$ amitriptyline for OCT2 inhibition), for $5 \mathrm{~min}$ at $37^{\circ} \mathrm{C}$. Intracellular accumulated levels of fenamiphos and phosmet were then quantified by liquid chromatography-tandem mass spectroscopy. Data are the means \pm SEM of three independent assays. NS, not statistically significant. 

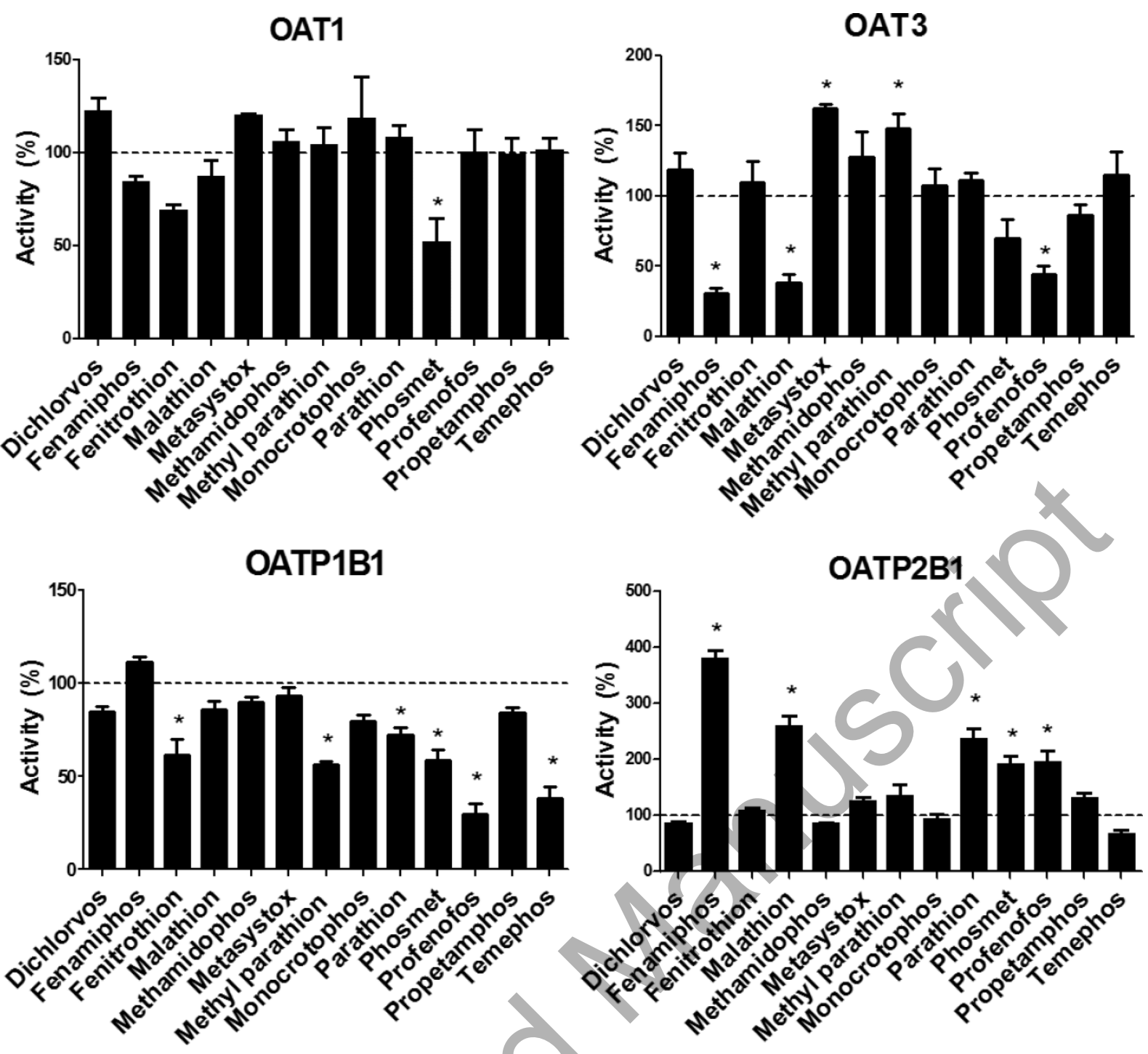

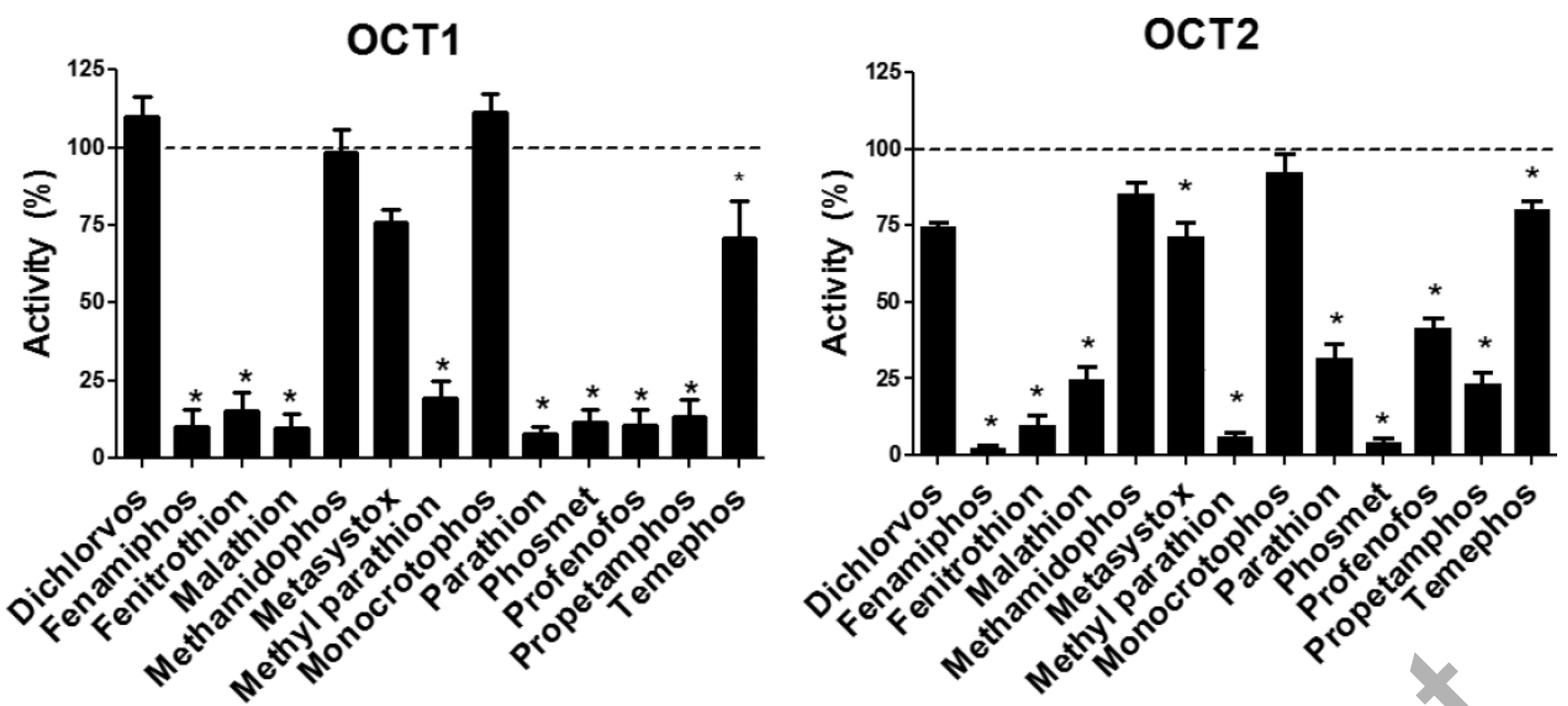

MATE1
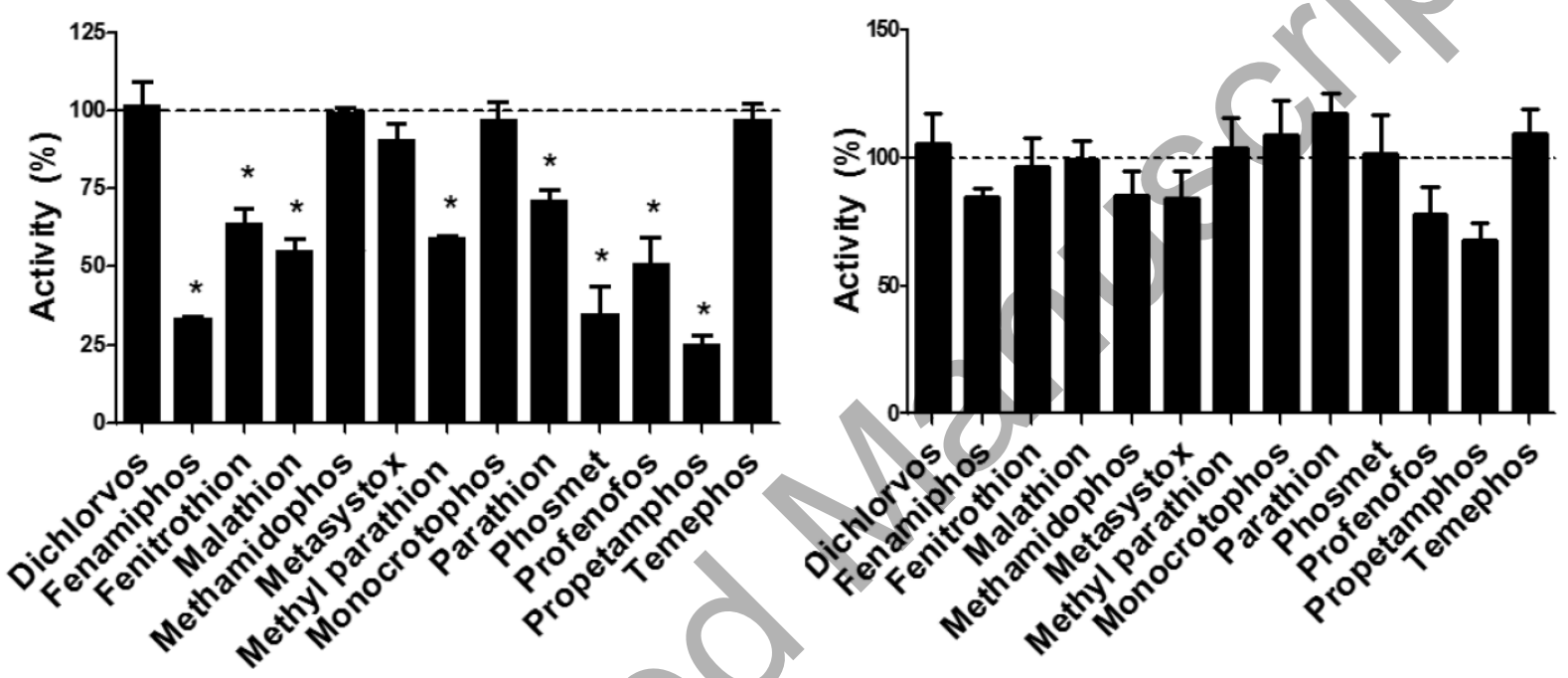
A
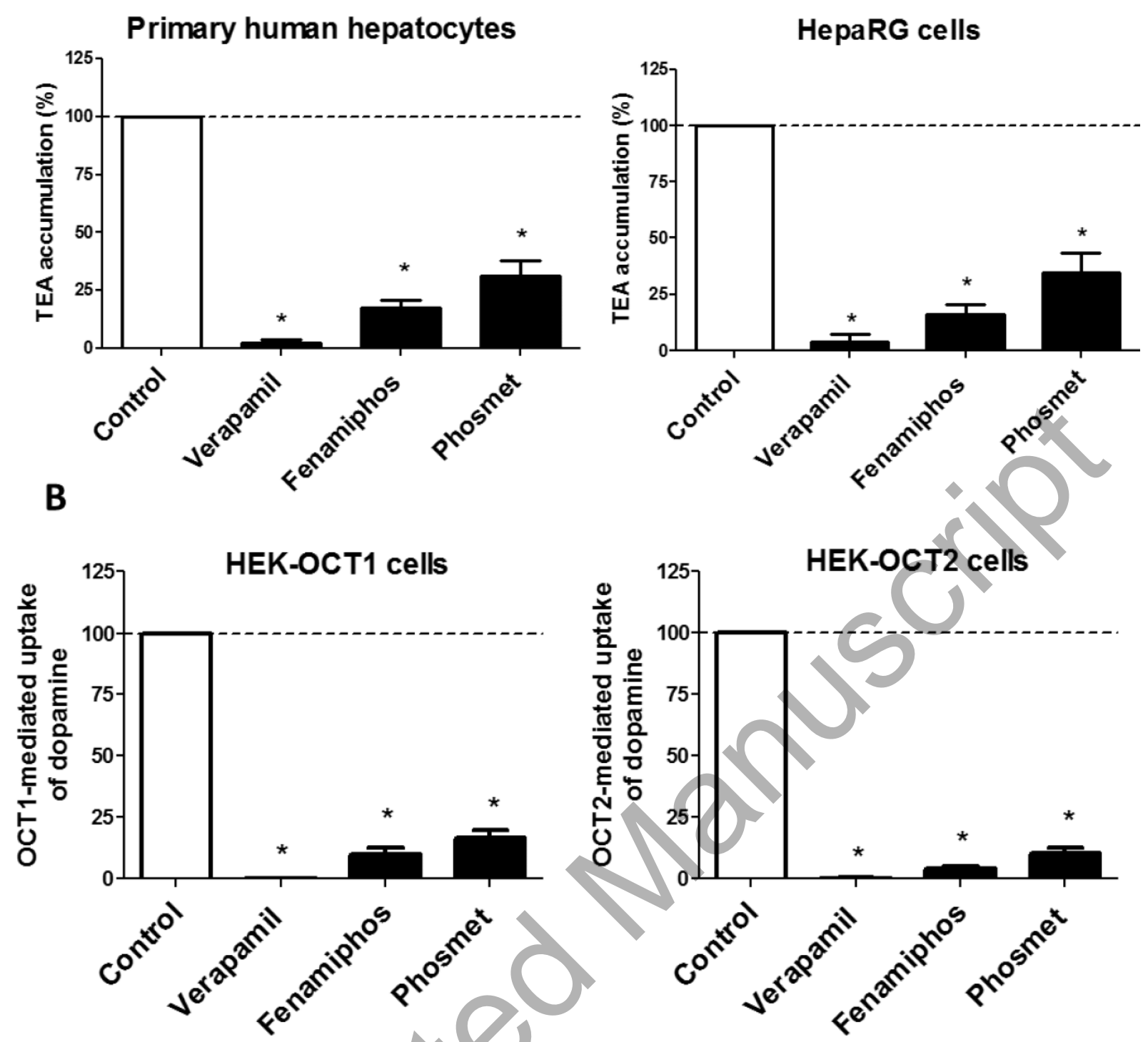
OCT1/Dopamine

$\mathrm{IC}_{50}=9.2 \pm 1.1 \mu \mathrm{M}$

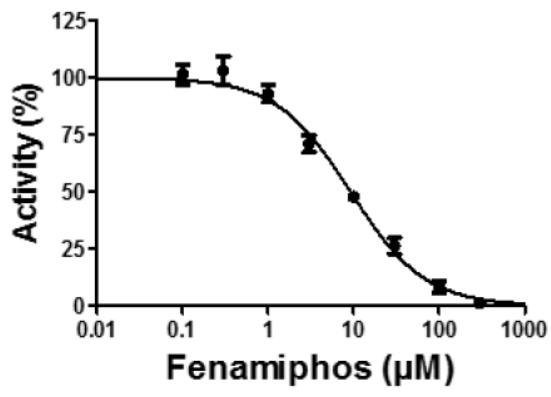

OCT1/DAPI

$I_{50}=27.5 \pm 1.2 \mu \mathrm{M}$

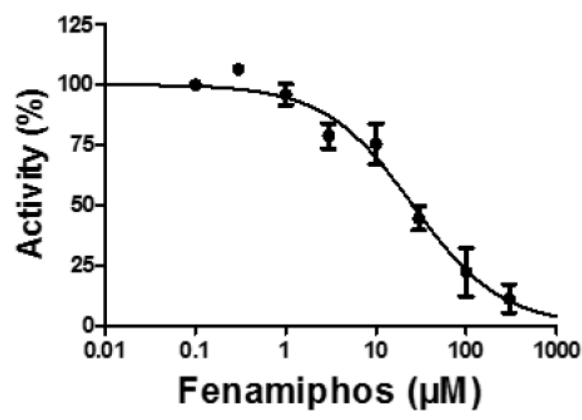

OCT2/Dopamine

$\mathrm{IC}_{50}=2.8 \pm 1.1 \mu \mathrm{M}$

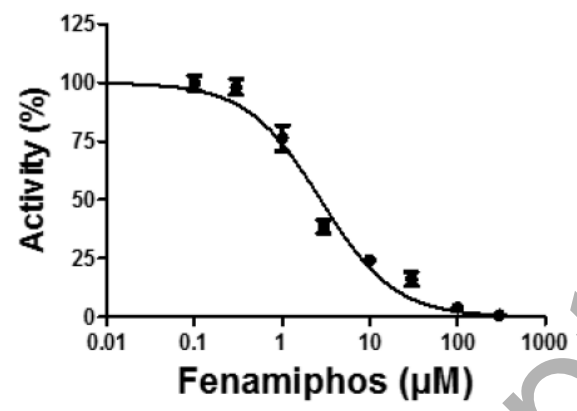

OCT2/Rhodamine 123

$\mathrm{IC}_{50}=6.9 \pm 1.1 \mu \mathrm{M}$

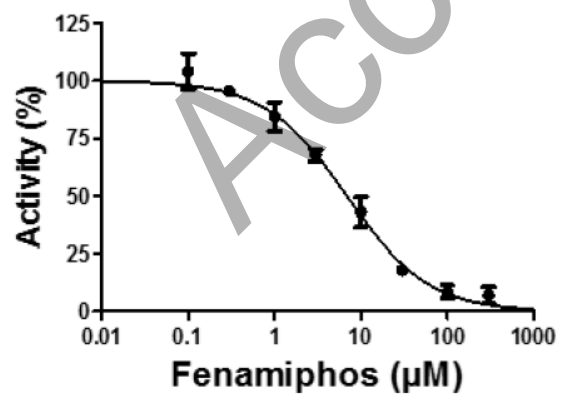

OCT1/Dopamine

$I_{50}=7.1 \pm 1.2(n=3)$

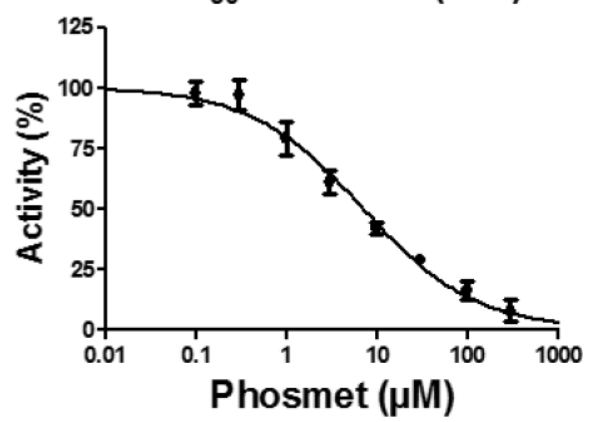

OCT1/DAPI

$I C_{50}=10.4 \pm 1.2 \mu \mathrm{M}$

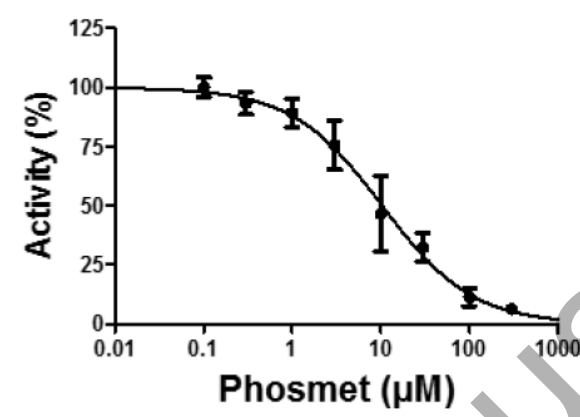

OCT2/Dopamine

$\mathrm{IC}_{50}=3.6 \pm 1.1 \mu \mathrm{M}$

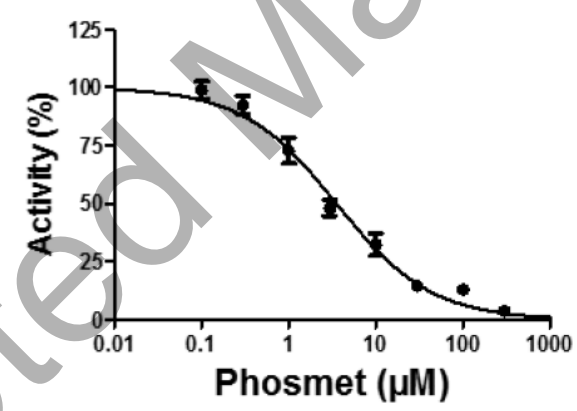

OCT2/Rhodamine 123

$I_{50}=7.9 \pm 1.2 \mu \mathrm{M}$

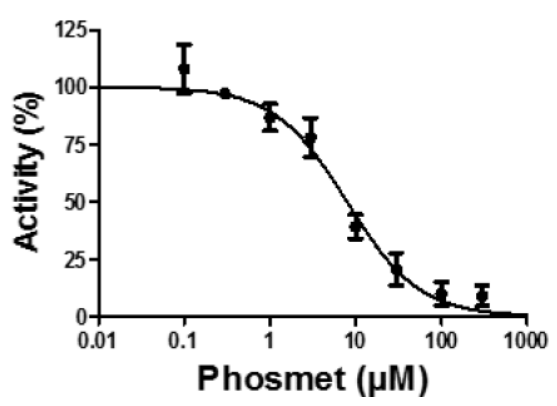


A

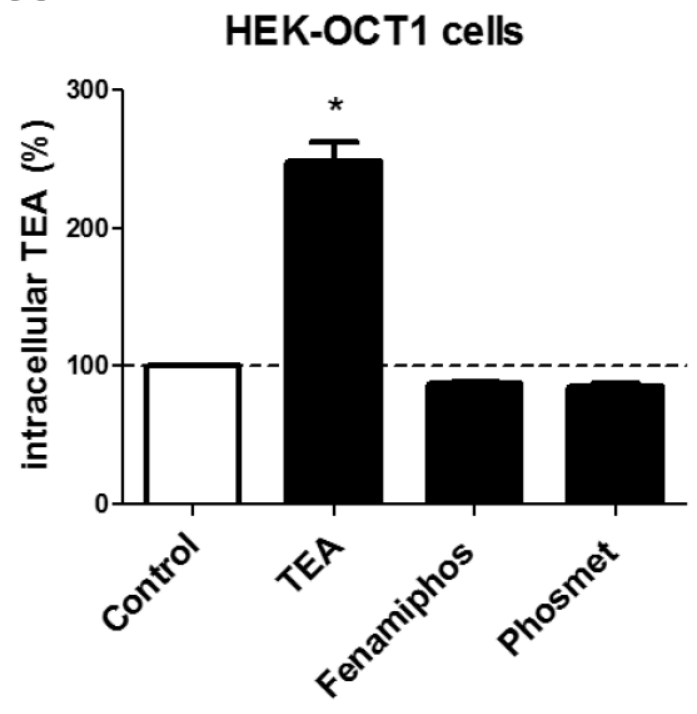

B

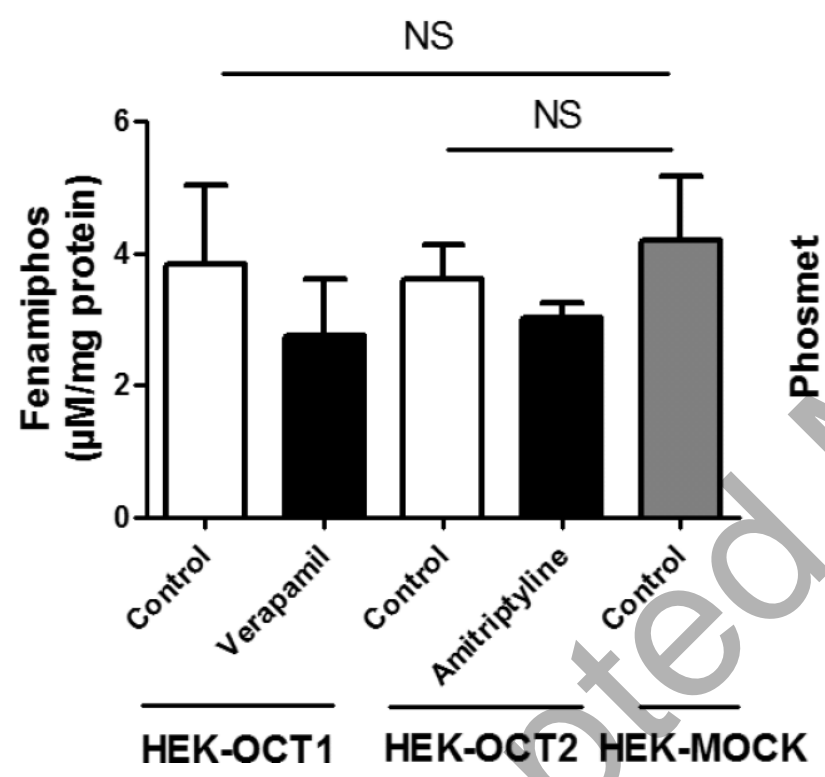

HEK-OCT2 cells

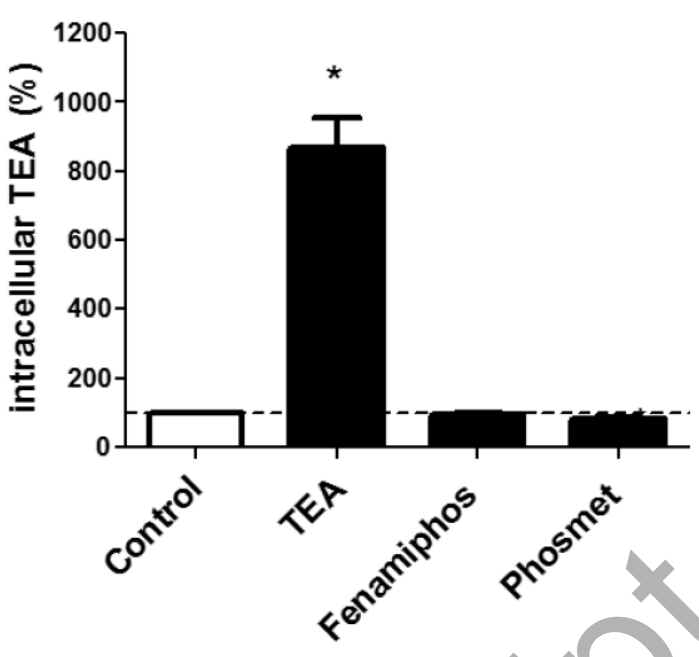

NS

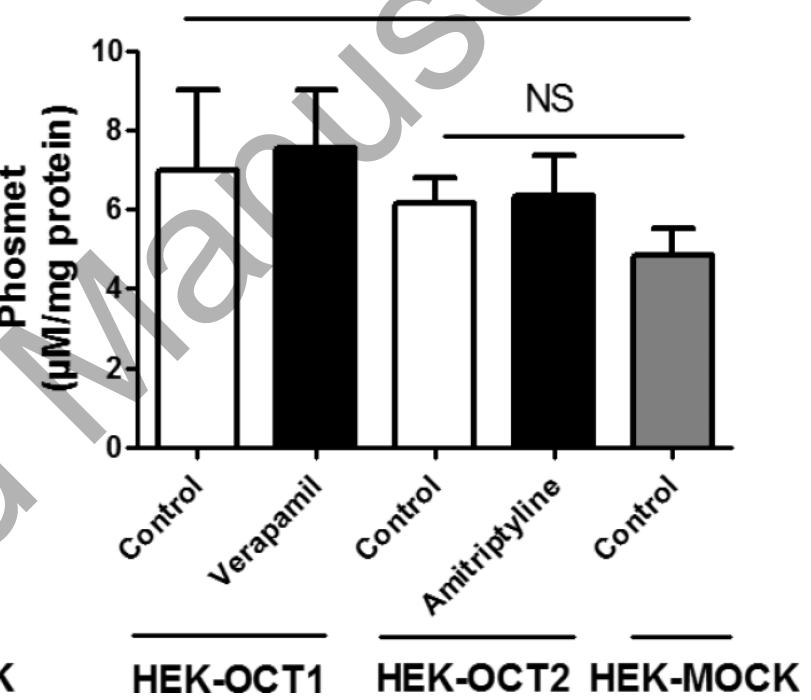




\section{Table 1}

Summary of OP effects towards SLC transporter activities

\begin{tabular}{cccccccccc}
\hline \multirow{2}{*}{ OP } & \multicolumn{7}{c}{ Modulation of SLC transporter activity } \\
\cline { 2 - 9 } & OAT1 & OAT3 & OATP1B1 & OATP2B1 & OCT1 & OCT2 & MATE1 & MATE2-K \\
\hline Dichlorvos & $=$ & $=$ & $=$ & $=$ & $=$ & $=$ & $=$ & $=$ \\
\hline Fenamiphos & $=$ & - & $=$ & + & - & - & - & $=$ \\
\hline Fenitrothion & $=$ & $=$ & $=$ & $=$ & - & - & $=$ & $=$ \\
\hline Malathion & $=$ & - & $=$ & + & - & - & $=$ & $=$ \\
\hline Metasystox & $=$ & + & $=$ & $=$ & $=$ & $=$ & $=$ & $=$ \\
\hline Methamidophos & $=$ & $=$ & $=$ & $=$ & $=$ & $=$ & $=$ & $=$ \\
\hline Methyl parathion & $=$ & $=$ & $=$ & $=$ & - & - & $=$ & $=$ \\
\hline Monocrotophos & $=$ & $=$ & $=$ & $=$ & $=$ & $=$ & $=$ & $=$ \\
\hline Parathion & $=$ & $=$ & $=$ & + & - & - & $=$ & $=$ \\
\hline Phosmet & $=$ & $=$ & $=$ & + & - & - & - & $=$ \\
\hline Profenofos & $=$ & - & - & + & - & - & $=$ & $=$ \\
\hline Propetamphos & $=$ & $=$ & $=$ & $=$ & - & - & - & $=$ \\
\hline Temephos & $=$ & $=$ & - & $=$ & $=$ & $=$ & $=$ \\
\hline
\end{tabular}

${ }^{a}$ The cut-off value was at least $50 \%$ increase (stimulation) or $50 \%$ decrease (inhibition) of transporter activity by OPs (tested at $100 \mu \mathrm{M}) .+$, stimulation; -, inhibition; =, no change.

\section{Table 2}

Combination index (CI) values for OCT2 inhibition by combined treatment with fenamiphos and phosmet

\begin{tabular}{cccc}
\hline \% inhibition OCT2 activity & CI $^{\mathbf{a}}$ & Mixture concentration $^{\mathbf{b}}$ & Nature of effect $^{\mathbf{c}}$ \\
\hline 10 & 0.43 & $0.38 \mu \mathrm{M}$ & Synergistic \\
20 & 0.51 & $1.00 \mu \mathrm{M}$ & Synergistic \\
30 & 0.58 & $1.90 \mu \mathrm{M}$ & Synergistic \\
40 & 0.64 & $3.21 \mu \mathrm{M}$ & Synergistic \\
50 & 0.71 & $5.19 \mu \mathrm{M}$ & Synergistic \\
60 & 0.79 & $8.40 \mu \mathrm{M}$ & Synergistic \\
70 & 0.90 & $14.18 \mu \mathrm{M}$ & Additive \\
80 & 1.05 & $26.85 \mu \mathrm{M}$ & Additive \\
90 & 1.34 & $70.22 \mu \mathrm{M}$ & Antagonistic \\
\hline
\end{tabular}

${ }^{\mathrm{a} C I}$ values were calculated using CompuSyn software.

${ }^{\mathrm{b}}$ The ratio [Fenamiphos]:[Phosmet] is $1: 1$.

${ }^{\mathrm{C}}$ Synergistic effect: $\mathrm{CI}<0.8$; additive effect: $0.8 \leq \mathrm{CI} \leq 1.2$; antagonistic effect: $\mathrm{CI}>1.2$. 